\title{
PHENOTYPIC AND GENETIC CORRELATION OF REPRODUCTION TRAITS IN SIMMENTAL COWS
}

\author{
Nebojša Lalić ${ }^{1}, Z_{\text {Zvonko Spasić }}{ }^{,}$Božidar Milošević ${ }^{1}$, Milinko Milenković $^{1}$, Nikola Stolić ${ }^{2}$ \\ ${ }^{1}$ University of Priština, Faculty of Agriculture, \\ Kosovska Mitrovica, Jelene Anžujske b.b., 38228, Zubin Potok, Serbia \\ ${ }^{2}$ Agricultural College, Prokuplje, Serbia \\ dr.lalicn@gmail.com
}

\begin{abstract}
Many of cows' production traits are, mostly, interrelated so for those kinds of relationship are said it is a correlative relation of traits. The phenotypic correlation between two quantitative traits depict a value to which individuals upwards of the average value for one trait intend to be above, below or close to the average value for another trait. However, phenotypic correlations initiate the question what is the degree of influence of the genetic basis on observing the association between two traits and what is the influence of exogenous factors. Derived data about tested reproduction traits interrelation, at a Simmental cow farm, are very important for a simultaneous selection of cows in many traits. The average service period length of the total investigated population was 147 days, which was about 1.5 fold longer in regard to the upper value of the optimal level. That had a significant influence on duration of the first inter-birth interval which averaged 436.3 days. The average duration of pregnancy was 283.4 days and the age at the first calving 872 days. The defined genetic correlation coefficients between cows' fertility traits, in the herd, exceed analogous phenotypic correlations in all cases. The genetic interrelation of tested fertility traits ranged from powerless to very strong (from 0.209 to 0.941 ). Phenotypic correlations among reproductive traits ranged from negative $(-0.131)$ to strong $(0.888)$, which was with high statistical significance $(\mathrm{P}<0.01)$.
\end{abstract}

Key words: cattle; Simmental; fertility; genetic correlation; phenotypic correlation

\section{ФЕНОТИПСКА И ГЕНЕТСКА КОРЕЛАЦИЈА НА РЕПРОДУКТИВНИТЕ СВОЈСТВА КАЈ СИМЕНТАЛСКИТЕ КРАВИ}

\begin{abstract}
Многу од производните својства на кравите се во меѓусебен сооднос, така што за таквиот вид врска може да се каже дека е корелативна релација на својствата. Фенотипската корелација меѓу две квантитативни својства дава вредност според која индивидуалните варирања на просечната вредност на едно својство се поголеми, пониски или блиски на просечната вредност на друго својство. Имено, фенотипските корелации иницираат прашање за тоа кој е степенот на влијание на генетската база на набљудуваната асоцијација меѓу две својства и какво е влијанието на надворешните фактори. Податоците за меѓусебните односи на тестираните репродуктивни својства добиени на една фарма на сименталски крави се многу важни за синхронизирана селекција на кравите за многу својства. Просечната должина на сервисен периодот кај вкупната испитана популација изнесуваше 147 дена, што е околу 1,5 пати повеќе во однос на горната вредност на оптималното ниво. Тоа имаше значајно влијание на траењето на првиот меѓутелидбен период, кој просечно изнесуваше 436,3 дена. Просечното траење на гравидноста изнесуваше 283,4 дена, а возраста при првото телење беше 872 дена. Коефициентите на генетската корелација меѓу фертилните својства на кравите во стадото ги надминуваат аналогните фенотипски корелации во сите случаи. Генетскиот меѓусебен однос на тестираните фертилни својства се движи од многу низок до многу висок $(0,209-0,941)$. Фенотипската корелација меѓу репродуктивните својства се движи од негативна $(-0,131)$ до јака $(0,888)$, што е со висока статистичка значајност $(\mathrm{P}<0,01)$.
\end{abstract}

Клучни зборови: симентал; плодност; генетска корелација; фенотипска корелација 


\section{INTRODUCTION}

Reproduction is a complex trait with many components. As a selection criteria measures of the reproductive performance are used, such as the service period, the inter-birth interval, the pregnancy duration, the age at insemination, the age at first calving, and so on (Rege \& Famula, 1993; Van der Merwe \& Schoeman, 1995; Spasić, 2009). Fertility in domestic animals is at the first place a very important biological trait with high economic importance, thus in livestock production farmers are paying great attention to this sequence during the production cycle. Fertility traits are under influence of many genetic factors, but at the same time environmental factors are of great importance. The Simmental cattle is a dual-purpose breed, but most of the farmers want to utilize these animals for milk production. Thus it is very important to know what genetic parameters are and how they influence the animal's performance. Several studies have shown that reproductive efficiency decline with the increased milk yield. A negative association between fertility and milk yield has been reported in cattle (De Vries and Risco, 2005).

In order to be able to make an adequate estimate of animal breeding values and establish an appropriate animal selection process, it necessary to estimate genetic parameters, such as genetic and phenotypic correlations, heritability and variability of desired traits. Many of cows' production traits are, mostly, interrelated so for those kinds of relationship are said it is a correlative relation of traits. The phenotypic correlation between two quantitative traits depict the value to which individuals upwards of the average value for one trait intend to be above, below or close to the average value for another trait. However, phenotypic correlations initiate the question what is the degree of influence of the genetic basis on observing association between two traits and what is the influence of exogenous factors. Genetic correlations are very important for the selection process since these coefficients depict the level of change of one trait as a result of change of another trait. Knowledge about genetic parameters provide possibility for so called simultaneous selection, or selection on several traits.

The aim of this paper was to define reproduction parameters in a population of Simmental cows, and to estimate phenotypic and genetic correlation coefficients.

\section{MATERIAL AND METHODS}

The research has been conducted on 249 animals of domestic spotted breed. The data of fertility traits has been collected from the farm and processed using statistical software Instat-prism, which is adapted for biological research. Fertility traits included in the research were:

- age at the first conception (AFC),

- gestation length (GL),

- age at the first calving (AC),

- service period (SP) and

- intercalving period (IP).

Correlation between traits has been determined via coefficients of phenotypic correlation $(r p)$ using the formula:

$$
r p=\frac{\operatorname{Cov}_{(A B)}}{\sqrt{s_{(A)}^{2} s_{(B)}^{2}}}
$$

where:

$\operatorname{Cov}_{(A B)}=$ covariance for traits A and B;

$s_{(A)}^{2}=$ variance for trait $A$ and $s_{(B)}^{2}=$ variance for trait $B$.

Standard errors of correlations have been determined using the formula:

$$
S r=\frac{\sqrt{1-r^{2}}}{\sqrt{n-2}},
$$

where:

$r=$ coefficient of phenotypic correlation;

$n=$ number of pairs.

Testing of obtained phenotypic correlation coefficients has been discussed by Romer-Orfal's, classification.

Genetic correlation coefficients have been calculated using the variance and covariance analysis, by methodology that has been created by Hazel and cited by Latinović (1996):

$$
r_{g}=\frac{\operatorname{Cov}_{x y}}{\sqrt{\operatorname{Var}_{B B} \operatorname{Var}_{W B}}},
$$

where:

$\operatorname{Cov}_{x y}=$ covariance of traits;

$\operatorname{Var}_{B B}=$ variance between sires;

$\operatorname{Var}_{W B}=$ variance within sires.

The standard error of genetic correlation coefficients has been calculated using an approxima- 
te method created by Robertson and cited by Pogačar (1974):

$$
S r_{g}=\left(t-r_{G}^{2} \sqrt{\frac{\left(h_{A}^{2}-\frac{4}{k}\right) \sqrt{\frac{2}{s}\left(h_{B}^{2}+\frac{4}{k}\right)} \sqrt{\frac{2}{s}}}{2 k_{A}^{2} h_{B}^{2}}},\right.
$$

where:

$$
\begin{aligned}
& h_{A}^{2}=\text { heritability of the trait A; } \\
& k=\text { average number of daughters per sire; } \\
& h_{B}^{2}=\text { heritability of the trait } \mathrm{B} ; \\
& s=\text { number of sires. }
\end{aligned}
$$

\section{RESULTS AND DISCUSSION}

The results regarding the average values and variability of fertility traits have been given in Table 1.

Table 1

Average values and variability of fertility traits

\begin{tabular}{lcccc}
\hline \hline Trait & $\bar{X}$ & $\mathrm{SD}$ & $S \bar{x}$ & $\mathrm{CV}$ \\
\hline Service period & 147.75 & 106.79 & 6.76 & 72.28 \\
Intercalving period & 436.33 & 123.78 & 7.84 & 28.37 \\
Age at the first calving & 871.83 & 82.80 & 5.24 & 9.59 \\
$\begin{array}{l}\text { Gestation length } \\
\begin{array}{l}\text { Age at the first } \\
\text { conception }\end{array}\end{array}$ & 283.40 & 10.41 & 0.66 & 3.66 \\
\hline \hline
\end{tabular}

The average duration of the service period was 147.7 days, with standard deviation of 106.7 days. The variability of the service period was high, actually it lasted about 1.5 fold longer in regard to the upper value of the optimal level, which illustrates the low level of management. That had a significant influence to duration of the first interbirth interval which averaged 436.3 days. The average duration of pregnancy was 283.4 days and the age at the first calving was 872 days, with the variation coefficient of 9.59. These results are in accordance with other authors who treated this subject on cows (Stojić, 1996; Spasić 1996; Janžeković et al., 2004; Medić et al., 2006; Spasić, 2009).

The summary of the obtained genotypic and phenotypic correlation is given in Table 2. Defined genetic correlation coefficients between cows' fertility traits, in the herd, exceed analogous phenotypic correlations in all cases. The genetic interrelation of tested fertility traits ranged from powerless to very strong (from 0.209 to 0.941 ). Phenotypic correlations among reproductive traits ranged from negative $(-0.131)$ to strong $(0.888)$, which was with high statistical significance $(\mathrm{P}<0.01)$. Complete genetic and phenotypic correlation has been determined between the age at the first insemination and the age at the first calving, as well as intercalving period, which has been expected, since the intercalving period is directly dependent on the gestation length and the service period. This confirms that these traits are under the control of the same additive genes. The gestation length is identical for all investigated animals with the smallest variability. Coefficients of the phenotypic correlation are very low, except those between the age at conception and calving and the service period and intercalving period. The presented results regarding the genetic and phenotypic correlation corespond to the results presented by other authors (Spasić, 2000; Biffani et al., 1995; Sajjad et al., 2009).

Table 2

\section{Coefficients of the genotypic and phenotypic correlation and their standard errors of fertility traits}

\begin{tabular}{ccccccc}
\hline \hline \multicolumn{2}{c}{ Trait } & $r_{g}$ & $S r_{g}$ & $r_{p}$ & $S r_{p}$ & $t_{\exp ,\left(r_{p}\right)}$ \\
\hline \multirow{4}{*}{ AFC } & GL & 0.209 & 0.142 & -0.032 & 0.035 & -0.518 \\
& AC & 0.941 & 0.056 & 0.888 & 0.029 & 30.413 \\
& SP & 0.899 & 0.320 & 0.044 & 0.063 & 0.701 \\
& IP & 0.881 & 0.180 & -0.131 & 0.063 & -2.080 \\
\hline & AC & 0.446 & 0.391 & 0.042 & 0.064 & 0.661 \\
GL & SP & 0.300 & 0.488 & -0.105 & 0.063 & -1.662 \\
& IP & 0.318 & 0.439 & -0.028 & 0.063 & -0.448 \\
\hline \multirow{2}{*}{ AC } & SP & 0.774 & 0.315 & -0.027 & 0.065 & -0.439 \\
& IP & 0.181 & 0.472 & -0.124 & 0.063 & -1.967 \\
\hline SP & IP & 0.938 & 0.002 & 0.950 & 0.063 & 2.039 \\
\hline \hline
\end{tabular}

\section{CONCLUSIONS}

On the basis of the results obtained regarding variability and correlation of reproductive traits in 
the population of Simmental cows, we can conclude a low productive and reproductive ability, but, in the same way, a high level of variability, which should be utilized for promotion of production and reproduction in the wide population. The obtained genetic and phenotype correlation coefficients between reproductive abilities are important factors for future actions. Knowledge about these parameters is very important and indicates a need for careful selection implementation in order to avoid negative effects, especially regarding the application of modern statistical methods and multitrait selection.

\section{REFERENCES}

[1] Biffani S., R. Canavesi, A. B. Samore (2005): Estimates of genetic parameters for fertility traits of italian holsteinfriesian cattle. Stočarstvo, 59:(2) 145-153.

[2] De Vries A., Risco C. (2005): Trends and seasonality of reproductive performance in Florida and Georgia dairy herds from. J. Dairy Sci., 88: 3155-3165.

[3] Janžeković M., Škorjanc D., Smolinger J. (2004): The influence of various origins of first calving Simmental and Black-white cows on production and content of milk. Mljekarstvo, 54 (4) 275-283.

[4] Medić D., Veselinović S., Veselinović Snežana, Ivančev Anica, Čupić Z. (2006): Uporedna ispitivanja osobina mlečnosti simentalskih krava domaće i austrijske provenijence. Simpozijum "Stočarstvo i agroekonomija u tranzicionim procesima". Herceg Novi.

[5] Rege, J. E. O. \& Famula, T. R., (1993): Factors affecting calving date and its relationship with production traits of Hereford dams. Anim. Prod., 57, 385.

[6] Sajjad T., Abdol S., Mohammad M., Mohammad D. (2009): Genetic analysis of reproduction traits and their relationship with conformation traits in Holstein cows, Livestock Science, 125, 1, 84-87, October 2009.

[7] Spasić Z. (1996): Varijabilnost i povezanost osobina mlečnosti i plodnosti tri generacije domaćih šarenih goveda. Magistarska teza. Poljoprivredni fakultet. BeogradZemun.

[8] Spasić Z. (2000): Kvantitativno genetska analiza proizvodnih i reproduktivnih osobina krava u populaciji crnobelih goveda. Doktorska disertacija. Poljoprivredni fakultet. Kruševac.

[9] Spasić Z., Milošević B., Milenković M., Stolić N. and Ilić Z. (2009): Phenotypic correlation of production and reproduction traits of cows in the population of dommestic spotted cattle. Research people and actual tasks on multidisciplinary sciences, Lozenec, Bulgaria. Proccedings, 155-161.

[10] Stojić, P. (1996): Faktori korekcije osobina mlečnosti $i$ njihov doprinos oceni priplodne vrednosti bikova i krava. Doktorska disertacija. Poljoprivredni fakultet, Beograd.

[11] Van der Merwe, P. S. \& Schoeman, S. J. (1995): Effect of early calving of Simmentaler heifers under an extensive management system. S. Afr. J. Anim. Sci., 25, 36. 